\title{
THE FOLK WISDOM OF A
}

MARITIME COMMUNITY

IN SELECTED WORKS BY

ARENA WATI: A STUDY OF

AN INTANGIBLE CULTURAL

HERITAGE

(Petua Masyarakat Maritim dalam Karya Terpilih Arena Wati: Satu Kajian Warisan Budaya Tidak Ketara)

Fatihah Che Mat

tiehah_fatihah@yahoo.com

Sohaimi Abdul Aziz

soaazz@usm.my

School of Humanities,

Universiti Sains Malaysia,

11800 USM, Pulau Pinang, Malaysia.

\section{Abstract}

Arena Wati is a literary figure who was once a seaman before he became a writer. His many experiences as a seaman are recorded in his works. Much of the cultural heritage of Macassar's maritime community known to Arena Wati has not been researched, including the folk wisdom that is typical of such a community. Folk wisdom is an example of intangible cultural heritage. This essay will discuss the folk wisdom of this maritime community, as portrayed by Arena Wati in the works studied. The method used for this study is textual analysis. The works relevant to this study are Arena Wati's memoir entitled Memoir Arena Wati: Enda Gulingku and four of his novels: Pantai Harapan (Shores of Hope) (1990), Citra (Image) (1991), Sudara (Kin)(1994), Warna Sukma Usia Muda (The Colours of a Young Soul) (2005) and Rindu Aroma Padi Bunting (A Longing for the Fragrance of Ripe Paddy)(2012).This study finds that the maritime folk wisdom presented by Arena Wati can be 
categorized into four: that of seamen, for ship passengers, that of fishermen and that of coastal communities.

Keywords: intangible cultural heritage, maritime communities, folk wisdom, Arena Wati

\begin{abstract}
Abstrak
Arena Wati merupakan sasterawan yang pernah menjadi pelaut sebelum menjadi sasterawan. Banyak pengalamannya sebagai pelaut ditulis dalam karyanya. Banyak warisan budaya masyarakat maritim Makassar yang diketahui oleh Arena Wati belum dikaji termasuklah petua. Maka, esei ini akan membincangkan petua sebagai warisan budaya tidak ketara masyarakat maritim seperti yang diperlihatkan oleh Arena Wati dalam karya yang dikaji. Kajian ini menggunakan kaedah analisis tekstual untuk meneliti petua berkenaan. Antara karya yang digunakan ialah memoir Arena Wati yang bertajuk Memoir Arena Wati: Enda Gulingku (2010) dan enam buah novelnya iaitu Pantai Harapan (1990), Citra (1991), Sudara (1994), Warna Sukma Usia Muda (2005) dan Rindu Aroma Padi Bunting (2012). Kajian ini mendapati terdapat petua maritim yang ditampilkan oleh Arena Wati dapat dikategorikan kepada empat, iaitu pelaut, penumpang kapal, nelayan dan masyarakat pesisir pantai.
\end{abstract}

Kata kunci: warisan budaya tidak ketara, masyarakat maritim, petua, Arena Wati

\title{
INTRODUCTION
}

The sea plays a very important role in the development of human civilization, especially in that of Malay society before the advent of air travel. This is due to the social, political, economic and cultural ties between islands. The majority of Malay seamen still live on islands in the Malay archipelago, subject to the tropical climate, seasonal wind patterns and strong ocean currents between islands and seas that are rich in nature's bounty. In addition, their settlements are located close to the sea and river banks, and as such a major portion of their life and culture are influenced by the coastal way of life which requires seamen to be tough and possess a strong spirit. They are skilled boat makers, hardy fishermen, brave and efficient seafarers, as well as excellent and successful traders. Their culture lies at the core of Malay civilization and Malay cultural heritage.

The seamen's cultural heritage is widely documented in various forms, both formal and informal. Literary works are one informal way for documenting 
cultural heritage. This is because literature is also an important cultural heritage; literature and culture cannot be separated. Culture encompasses values, beliefs and habits which can be recorded in literature. Looking into literary works is also looking at the values, beliefs and habits of the people in the area from where these literary works originate. Literature is a heritage of symbols, or a collective symbolism of previous generations. Observing these collective symbols means looking at the cultural heritage of a nation where the values, beliefs and behaviour interact with the environment (Mahyuddin, 2008). Studying our cultural heritage can help us understand our current situation and predict the future as well. Preserving and upholding literature as a cultural heritage requires a high degree of creativity and ample space for the development of a great cultural heritage (Sohaimi, 2014:134-35).

Arena Wati is one author who portrays the seamen's cultural heritage in his works. There are some studies that discuss Arena Wati's works including an essay entitled "Minda Pelaut dan Kenangan Tanah Leluhur dalam Kepengarangan Arena Wati: Tafsiran Fenomenologi" (The Mind of the Seaman and Memories of Ancestral Land in Arena Wati's Writing: A Phenomenological Interpretation) by Kamarudin M. Said, that was included in "Minda Pelaut dan Kenangan Tanah Leluhur Kemelayuan MalaysiaIndonesia" (The Mind of the Seaman and Memories of Malaysian-Indonesian Malay Ancestral Land) (Rahim ed., 2012). This essay discusses how the mind of a seaman like Arena Wati is expressed in his writings. His sensitive perception of a phenomenon enables him to transform a normal one into a transcendental phenomenon in narrative. Kamarudin has attempted to highlight the transcendental phenomenological features of Arena Wati's writings, especially in Sukma Angin (The Soul of the Wind).

In addition, Sohaimi, in his essay "Arena Wati dan Makassar: dari Pelayar dan Pedagang ke Pengarang Cereka Maritim" (Arena Wati and Macassar: from Sailor and Trader to Writer of Maritime Tales) in the Persidangan Kebangsaan Dunia Maritim Nusantara dalam Pelbagai Perspektif: Sasterawan Negara Arena Wati sebagai Pelayar, Pedagang dan Pengarang (National Conference for the Maritime World of Nusantara in Various Perspectives: National Laureate Arena Wati as Seaman, Trader and Author), held on 24 October 2015, also discusses Arena Wati's successful descriptions of the world of seamen and Macassar's maritime traders in his writings, which earned Arena Wati the distinction of National Literary Laureate. There have been studies on Arena Wati's maritime skills but none yet on the folk wisdom of the maritime community of Macassar in his works. 
Arena Wati, whose real name is Abdul Dahlan Abdul Biang alias Andi Mohammad Dahlan Andi Buyung, was born in Kalumpang, in the Jeneponto regency of South Sulawesi, Indonesia, in 1925. He was born into a family of seamen. His father and grandfather were seamen and traders. His grandfather, Abdul Fatah, was the owner of a padewakang, a type of large sailboat; at that time, only four families in Kalumpang owned such a boat. Arena Wati's father, too, was a seaman and a trader who sailed all the way to Singapore and Sumatera to trade. Arena Wati was trained by his father and mother in the art of sailing from a young age. From the age of five, his father had taken him sailing.

Arena Wati spent his youth exploring the world of sailing and maritime trading, and working as a cook, clerk, purser, and sailor. He worked his way up to helmsman, and became a captain at the young age of 17 . He was not only experienced in sailing but had also been on trading expeditions on British and Dutch steamships. This experience served as material for his creative works, especially his novels.

Based on the concept that literature is the reflection of the author himself, this article will show how Arena Wati portrays the seamen's cultural heritage in his memoir [Memoir Arena Wati: Enda Gulingku (2010)] and four of his novels, Pantai Harapan (Shores of Hope) (1990), Citra (Image) (1991), Sudara (Kin) (1994), Warna Sukma Usia Muda (The Colours of a Young Soul) (2005) and Rindu Aroma Padi Bunting (A Longing for the Fragrance of Ripe Paddy) (2012). These works have been selected to show how Arena Wati depicts the intangible cultural heritage of the maritime world. This essay, utilizing the textual analysis method, will analyse all these novels in order to explore the intangible cultural heritage of folk wisdom of a maritime community. A maritime community is a community that uses the sea as its source of income, or the basis of its economy. In other words, a maritime community is a society that is close to the sea such that the sea becomes part of their lives. Such a community includes sailors, traders, fishermen and those people living in the coastal areas for whom the sea is the main source of income.

\section{CULTURAL HERITAGE}

Heritage means something that is inherited from one generation to another and may include customs, culture, areas, buildings, archives and printed material, including books and magazines (A Ghafar, 2005:4). In the Malaysian 
context, the National Heritage Act 2005, cited by A. Ghafar (2005:4-5) classifies heritage as having two categories that is, natural heritage and cultural heritage. Natural heritage refers to any landforms or geologic features, such as mountains, rivers, streams, rock formations, shorelines or any other natural sites that have environmental or historical value.

The tangible and intangible cultural heritage that is in the form of property, structure and artifacts of culture includes objects, cloth, artifacts, structures, performances, dances, songs and music. Cultural heritage, because it has aesthetic value, is valuable in terms of archaeology, architecture, culture, history, science, social and spiritual aspects, linguistics and technology (A. Ghafar, 2005:5).

The National Heritage Act 2005 also divides cultural heritage into two types that is, tangible and intangible cultural heritage. Tangible cultural heritage is cultural material that is the result of human creation. The tangible heritage includes areas, monuments and buildings, while the intangible cultural heritage is abstract in nature. The latter includes language and oral traditions, songs and music, dance and theatrical performance, and arts of self-defense, or anything that forms a heritage from any part of Malaysia or Malaysian society (A Ghafar, 2005:4-5). Other cultural aspects related to behavior, thought, knowledge, values and beliefs are also considered intangible cultural heritage (Sohaimi, 2014:134-35).

\section{INTANGIBLE CULTURAL HERITAGE}

UNESCO is the highest world body that protects all forms of heritage including intangible cultural heritage. Abu Talib (2012:xiii, quoting from Corsane), says that the definition of intangible cultural heritage as defined by UNESCO, is as follows:

The intangible cultural heritage means the practice representations, expressions, knowledge, skill — as well as the instrument, objects, artefacts and cultural space associated therewith - that communities, groups and, in some cases, individuals recognize as part of their cultural heritage. This intangible cultural heritage, transmitted from generation to generation, is constantly recreated by communities and groups in response to their environment, their interaction with nature and their history, and provides them with a sense of identity and continuity, thus promoting respect for cultural diversity and human creativity ... 
The intangible cultural heritage, as defined above is manifested inter alia in the following domains: oral traditions and expressions, including language as a vehicle of the intangible cultural heritage; performing arts; social practices, rituals and festive events; knowledge and practices concerning nature and the universe; and traditional craftsmanship.

Based on this definition of intangible cultural heritage, the current article aims to show how Arena Wati, in his novels, highlights the folk wisdom of a maritime community, which is its intangible cultural heritage. The folk wisdom will be categorized into four groups, that is, seamen, ship passengers, fishermen and coastal inhabitants.

\section{FOLK WISDOM}

One example of intangible cultural heritage is folk wisdom. Folk wisdom includes useful advice, guidance or opinions on how to do or achieve something effectively. Folk wisdom also includes taboos, rules, practices and advice from the elders in a community. Folk wisdom is transmitted from person to person, and is practiced by the members of a community. Normally, folk wisdom is transmitted by elders to the younger generation (Yusmilayati, 2015: 279). Folk wisdom is also connected to customs and beliefs. Therefore, folk wisdom is often adapted and suited to the situation and environment of a particular community (Hamidah, 2013:90). Every community has its own set of folk wisdoms, and sometimes that of one may be similar to those of another. Folk wisdom is usually transmitted orally and commonly concerns making a task easier, curing ailments, or problem-solving. Some folk wisdom is meant to aid in maintaining beauty or health, or how to keep animals or insects away. Most of these do not have side effects and save cost because the material used is available in the natural environment of the community.

\section{The Folk Wisdom of Seamen}

Pieces of folk wisdom relevant to seamen can be found in Arena Wati's novels. Seamen here refers to the crew of a ship - sailors and their superiors - or, according to Malay maritime laws, those who are office-holders (Ahmad Jelani, 2006:164). One example of such folk wisdom is a tip for overcoming sleepiness. Seamen who are working overtime on instructions by the captain sometimes have to sacrifice their sleeping time in order to carry out their duties, to ensure safe passage until the ship reaches its intended destination. Arena Wati records what sailors do to prevent falling asleep while on duty: 
Aku Seru Koki, di pangkal layar kapi, "Bawa dapur kompor ke ruang kelasi! Bikin kopi. Untuk aku, jurumudi dan jurubatu; gambir. Untuk semua kelasi layar; garam!"

"Gambir semua! Jurumudi sambut. "Agar tak tidur sebelum lalui Selat Durian.”

(I called out to Koki at the front of the ship, "Bring the stove to the sailors' area! Make coffee. For me, the helmsman and leadsman: with gambier. For the sailors: with salt!"

"Gambier for everyone!" the helmsman cried. "So that you don't fall asleep before passing the Durian Strait.")

(Arena Wati, 2005:46)

"Engkau Hamad, dan beritahu Jalie juga, jangan beri kelasi kopi bergambir. Kopi itu terlalu keras. Cukup, andai terpaksa berikan kopi bergaram saja."

"You, Hamad — and tell Jalie too - don't give the sailors coffee with gambier. It's too strong. It's enough to give them coffee with salt, if you have to."

(Arena Wati, 2005: 76)

From the above examples, we can see that in order to overcome sleepiness, sailors would drink coffee mixed with salt and gambier. This is if they wanted to stay awake for a longer period of time. If they did not need to stay awake too long, drinking coffee mixed with salt alone was sufficient. Gambier is a type of dried resin obtained from the extract of the Uncaria gambir Roxb. leaves and stems (Syamsul and Rodami, 2015:124).

Normally, coffee mixed with gambier was prepared for the captain, helmsman and leadsman who need to stay awake much longer in order to monitor the surroundings of the ship, whereas coffee with salt was prepared for the ordinary sailors. However, in certain situations, the sailors were also given coffee with gambier, especially when they expected to face threats such as typhoons, coral reefs or pirate attacks.

Arena Wati also records what sailors would do to increase the speed of a boat. Folk wisdom advises the removal of barnacles and moss that attach to a boat. Barnacles growing on the hull of a boat will cause the surface to be uneven and therefore cause friction, thus affecting its speed. If the barnacles are not removed, the boat will decrease in speed. Arena Wati describes the cleaning of the hull in the following excerpt:

... petang tadi, kelasi telah selesai mengikis teritip dan mengopak semua lepa yang masih melekat pada papan. Malam ini, mereka sengaja tidak tidur. Mereka 
menunggu air pasang penuh. Kini, balok-balok galangan dok itu sudah digenangi air pasang. Air itu mereka harapkan untuk menggosok lumut, dan mengikis bekas tapak teritip itu pada papan dari lunas sehingga ke garis insuran. Apabila air surut, mereka akan bakar sehingga kering dengan api dari daun kelapa kering. Daun kelapa itu, kami beli dua lori dari tempinis dan hulu paya lebar.

(... this afternoon, the sailors scraped off all the barnacles and the remaining coating on the wood. Tonight, they will stay awake. They will wait for the high tide. Now, the piling of the dock was already submerged in high water. This was the water they needed to wash off the moss and scrape off the barnacle spots on the wood from the keel all the way to the water line. When the tide recedes, they will dry it by burning dry coconut leaves. For this purpose, we have bought two lorry loads of coconut leaves from Tempinis and Hulu Paya Lebar.)

(Arena Wati, 2005:103)

The above excerpt also conveys that the suitable time for removing the moss and barnacles is during high tide.

Another piece of folk wisdom is for destroying pests and removing the musty smell of the load in the hold of a ship after unloading the cargo at the dock:

... belerang yang dibakar seluruh ruang membunuh tikus, lipas, cecak, dan bubuk kopra dan membuang hapak muatan sudah berlalu dua jam, maka udara busuk bau belerang terbakar sudah dipulihkan, dengan membakar beberapa keping kopra dalam ruang ...

(... the burning of sulphur space kills rats, cockroaches, lizards and the bugs from the copra, and removes the musty smell of the cargo. After two hours, the pungent smell of burnt sulphur is cleared by burning some copra in the hold ...)

(Arena Wati, 2005:168)

As described in this passage, the sailors would burn sulphur to destroy pests such as rats, cockroaches, lizards and bugs. Sulphur is also burned to remove the musty smell of the cargo that lingers even after it has been unloaded onto the dock. This passage also highlights another piece of folk wisdom that is, how to remove the stinging smell of burnt sulphur by burning several pieces of copra. Copra is the flesh of the coconut that has been dried in the sun or by direct heat from the fire (Sutarmi and Hartin Rozaline, 2006:22). 


\section{Tips for Ship Passengers in Folk Wisdom}

Another piece of folk wisdom that Arena Wati describes is a folk cure for seasickness that often afflicts the passengers of a ship. Seasickness usually affects the passengers of a ship and rarely the crew, because the latter are used to being on the sea. The folk cure for seasickness is described in the novel Sudara. In this novel, Captain Sulong helps a seasick passenger, Raja Murliah, who is seven years old at the time. The 7 year old girl vomited yellow bile. Captain Sulong is described as bathing Raja Murliah with seawater until she shivers and then giving her wajik pahat, porridge and sugar syrup. Wajik pahat is a sweetmeat that seamen often took with them as it keeps for a long time. The description of the cure is as follows:

“... mandi air laut sampai menggigil. Nanti makan bubur dan air gula." Dia menoleh kepada bendahari yang sedang membantu kelasi ... Perlahan dia dudukkan Murliah di atas ribaannya, dan sebelah tangannya mencapai bakul rombong yang bertutup. Dari dalam bakul itu dia mengambil tiga ketul wajik pahat yang sudah dibalut daun pisang kering.

"Kalau mabuk, sebelum masak bubur, makan yang manis ini dulu," katanya perlahan. Dia menyerahkan sebiji kepada Raja Salmah dan sebiji kepada Gazeb. Bahagian Murliah dia bukakan balutnya. "Kalau Murliah dapat habiskan ini tentu tidak akan mabuk lagi."

(“... bathe her with sea water until she shivers. Then give her some porridge with sugar syrup." He turned to the purser who was helping a sailor.

... Slowly he sat Murliah on his lap, and reached out with one hand for the lidded woven basket. From inside the basket he took out three pieces of wajik pahat which had been wrapped in dried banana leaves.

"If you are sick again before the porridge is cooked, eat this sweet first" he said softly. He gave one piece to Raja Salmah and a piece to Gazeb. He unwrapped the piece meant for Murliah. "If Murliah can finish this, she will definitely not feel seasick anymore.”)

(Arena Wati, 1994:62)

Captain Sulong, according to this passage had given Raja Murliah wajik pahat to eat in order to get rid of the nauseous feeling as a result of seasickness. 
Wajik pahat also helps to increase body heat when a person is feeling cold, and prevents lasa-weakness or numbness. Lasa is a condition in which the body becomes numb (prpm.dbp.gov.my). The function of wajik pahat and the method of making it are described in the following passage:

Wajik pahat ini lebih banyak gula dari pulutnya dan kelapa gorengnya. Padat beku, keras macam batu. Setiap seketul sebesar telur itik, dibalut daun pisang kering dan dibebat serat iras batang pisang kering. Ini bekalan pelaut. Mereka makan apabila hujan atau terlalu sejuk untuk memanaskan darah mereka, dan mengelakkan diri daripada penyakit lasa. Seluruh anak perahu menerima bahagian masing-masing daripada bendahari tanpa kata, hanya dalam hati mereka berterima kasih dan menyanjung kemurahan hati nakhoda.

(Wajik pahat is made of sugar, glutinous rice and toasted coconut, with sugar being the main ingredient. Compact and solid, it is hard as rock. Each piece is as big as a duck egg. It is wrapped in dried banana leaves and tied with the fibres of the dried stem of a banana plant. This is the seamen's provisions. They eat this when it rains or it is too cold in order to warm the blood and to prevent numbness. Every member of the crew receives theirs from the purser without uttering a word, but in their hearts they are thankful for the captain's generosity, and respect him for it.)

(Arena Wati, 1994:64-65)

Apart from eating wajik pahat, there are other folk remedies used by the maritime community to avoid from coming down with weakness or numbness. Anyone who goes overboard and has spent a long time in the water may suffer from lasa. The folk remedy to overcome this is described by Arena Wati in his novel Warna Sukma Usia Muda (2005). Here, Daeng Nanjeng saves Sari Tunjang, who, as a result of having been in the water for a long time, becomes very weak and cannot move. Sari Tunjang is the child of the ship's owner. The ship, Sri Kejora, in which she sails, is hit by a bomb in an attack by a warplane. Rahim and Daeng Nanjeng carefully treat Sari Tunjang so that she will not develop lasa, which can cause numbness of the entire or part of the body. The folk remedy used to cure this was by giving the patient warm water, palm sugar and a porridge made from a mixture of sago flour, palm sugar and thin coconut milk. A cure known as jamu is also given to the patient. The jamu is made up of the ingredients described in the following passage: 
“... kau suruh Saleh ambil madu dan dua biji telur ayam, bekalan adunan jamu aku. Kamu sendiri bancuh dengan air panas sebelum jam sepuluh siang. Boleh kental sikit. Madu dan telur itu akan kuatkan sarafnya. Pukul sebelas, beri bubur beras. Itu akan pulihkan ususnya."

“... You! Ask Saleh to take some honey and two of the chicken eggs I brought that are meant for as jamu ingredients. Mix these with hot water before 10 in the morning. Do this yourself. If it's a bit thick, that's fine. The honey and eggs will strengthen her sinews. At 11, give her rice porridge. That will settle her bowels."

(Arena Wati, 2005:215)

This jamu, made from honey and eggs mixed with hot water is given as a cure to Sari Tunjang, who has become weak and exhausted after being immersed in sea water for a long time. This jamu has to be taken by Sari Tunjang before the rice porridge that is meant to settle her bowels.

\section{The Folk Wisdom of Fishermen}

The following piece of folk wisdom described by Arena Wati is used by fishermen to catch fish and to take catfish off the line without getting stung. In the novel Rindu Aroma Padi Bunting, Raja Burhan catches catfish with Majido and Raja Nongcik. The tip for catching catfish is found in the following passage:

... akhirnya, Majido mengaku kalah dalam pengalaman dan pengetahuan pada tabii ikan sembilang. Raja Burhan ajar, dan nakhoda itu amalkan, umpan pada mata kail, campurkan umang-umang laut dan isi kepah. Angkat ladung naik satu genggam penumbuk dari dasar laut.

(... finally, Majido admitted that he did not know much about the habits of catfish. The captain quickly learned from Raja Burhan that he should bait the fish hook with hermit crabs and clams. The plummet should be raised the height of about one fist from the bottom of the sea.)

(Arena Wati, 2012:389)

Raja Burhan also teaches Raja Nongcik how to take catfish off the fish hook, as well as how to remove the sting of the catfish. These pieces of folk wisdom are described in the following passage: 
Raja Burhan tergelak. "Pancing ladung saja begini yang boleh mendekat rapat pada pangkal tangguk kelong. Sembilang berlegar di sana." Dia naikkan ikan itu sebelum membebat tangan sendiri. "Ongchik, lihat cara abang kuasai sembilang ini, dan lucut mata kail dari mulutnya". Dia bantai semambu dan pulas tiga kali pada kepala sembilang untuk patahkan tiga duri dan melemahkan tenaganya, lalu lentangkan atas balak kuda-kuda tajak tiang, dan letak melintang semambu atas perut ikan itu, dan pijak semambu dengan kaki kiri. Tangannya cekatan dalam gelap di laut tanggalkan mata kail.

"Ongchik!" Raja Burhan tegur adiknya. "pastikan ketiga-tiga duri daripada setiap ikan sembilang itu, sudah patah baru tindih semambu dan rungkai mata kail."

(Raja Burhan laughed. "A dropline like this is the only one that can be used close to the fishing nets of the Kelong. Catfish are abundant there". He brought up the fish before wrapping his own hand. "Ongchik, look at how I handle the catfish, and remove the hook from its mouth". He took a stick and used it to twist off the three stings at the head of the catfish, thus weakening it, then stretched the fish across the trusses at the base of the support pillars, placed the stick across the belly of the catfish, then stepped hard on the stick with his left foot. Deftly, in the darkness surrounding the sea, he removed the fish hook.

"Ongchik," Raja Burhan reminded his brother "make sure all three of the catfish stings are broken, only then step on the stick and detach the fishhook.")

(Arena Wati, 2012:211, 213)

Although the method seems rather violent, this was how fishermen removed the dangerous stings of the catfish. Apart from this, there is a tip for catching crabs. According to Raja Burhan the best time to catch crabs is when the moon is not full. This is because at that time the crab claws are not strong and the crabs are fleshier:

"Tangkap ketam" Raja Burhan selamba. "Masa bulan tidak purnama begini, ketam laut gemuk, isinya padat. Sepitnya tidak kuat menggigit."

("The time to catch crabs," said Raja Burhan casually, "is when the moon is not full, like today. That's when they are fleshier. And their claws cannot pinch as strongly.”) 
Apart from the folk wisdom on catching catfish and crabs, Arena Wati also passes on a tip for cooking tuna in a way that the flesh of the fish does not cause irritation in the throat. In his novel Citra, he writes:

... cara memasak ikan tongkol (aya) agar dagingnya tidak gatal dengan memotong ekor ikan tongkol, buang darahnya dengan cara menggantungkannya agar semua darahnya habis keluar.

(... the way to cook tuna so that its flesh does not cause itching is to cut off the tail, and hanging it up so that all the blood will drain out.)

(Arena Wati 1991:20)

After the blood has drained out, the fish can be cooked without causing any itching.

\section{The Folk Wisdom of the Coastal Community}

In his works, Arena Wati also records the folk wisdom of the people living on the coast. Coastal communities are those people who live along the coast and whose livelihood depends on the sea. The folk wisdom of this community includes the method of collecting a type of zooplankton called renek. Renek are small organisms that live in the sea and are categorized as zooplanktons, and used as fish food (Hersanto, 1990:35). According to Arena Wati, renek is just the size of a pin when it is two or three days old. The activity of collecting renek takes place in October and December, which are the renek seasons in Macassar. It is carried out by children. It is a lucrative activity, and sometimes the children make more than an adult. The renek is sold to a renek collector (Arena Wati, 2010:59-63). The method of collecting renek is described by Arena Wati in his Memoir Arena Wati: Enda Gulingku, and is based on his own experiences as a child. Arena Wati was taught how to collect renek by an old man from his village, who was called Tata Kende. According to Arena Wati:

... Maka dia mengajar saya bagaimana cara menangkap renek dalam gelap gelita dinihari begitu.

"Bawa tempayan besar," katanya. "jangan gunakan mangkuk sia atau piring untuk mencedok. Gunakan lobo. Kaut saja dari sodo dan segera masukkan dalam tempayan. Anggarkan sekali kaut airnya satu perempat lobo saja." "Kaut walaupun tak nampak ada atau tidak ada renek?"

"Kaut saja," katanya meyakinkan. "Pada waktu begitu mesti banyak renek." 
(... He taught me how to collect renek in the utter darkness of the pre-dawn hours.

"Bring a big jar", he said. "Don't use a bowl or plate to scoop. Use a lobo. Just scoop from a sodo and immediately put it in the jar. Estimate the water in one scoop to be about one quarter of a lobo only."

"Scoop even though I can't see if there's renek or not?"

"Just scoop" he said reassuringly. "At those times there will definitely be a lot of renek.")

A lobo is the shell of the snail-shaped Nautilus species, while a sodo is a small fishing net made using a red-coloured muslin, and shaped into a triangle, about a yard in length and width, which is pushed three inches below the surface of the water (Arena Wati, 2010:240). The majority of Macassarese use a bowl or saucer to scoop renek from the sodo but Tata Kende taught Arena Wati to scoop using a lobo. Arena Wati also describes the steps to be taken when collecting renek that he was taught by Tata Kende:

Saya sorong sodo saya antara sepuluh hingga dua belas langkah sekali angkat, dan saya cedoklah permukaan dalam sodo itu dengan siput nautilus. Saya yakin dengan pengalaman itu, cara saya mencedok tidak akan banyak meninggalkan baki pada permukaan kain sodo. Oleh itu, sekali cedok saya bawalah ke darat dan dituang ke dalam labu. Labu ini saya isikan sedikit air tawar untuk menjamin kesihatan renek itu, supaya lekas membesar.

(I would push my sodo for ten to twelve steps before lifting it out of the water, and I would scoop the inner surface of the sodo with a nautilus shell. I was confident that with experience, the way I scooped would not leave much behind on the surface of the cloth of the sodo. Therefore, after every scoop I would go ashore and pour it into my container. This container I had filled with freshwater to ensure the renek would stay fresh and will grow quickly.)

(Arena Wati, 2010:61)

This method is suitable for collecting renek in the early hours of the morning, as it is still dark. The early hours of the morning are more suitable than daytime because the renek is abundant at that time (Arena Wati, 2010:59). Arena Wati preferred to collect renek in the early hours of the morning not only because there was abundant renek at that time but also 
because in the daytime he had to compete with other children. Arena Wati was so successful with this method that he was able to collect a lot of renek to sell to the renek collector.

Many of the people of Kalumpang dared not go out to collect renek in Mattete in the early hours of the morning because they had been told stories by Angge Jumba about there being a ghost in Mattete. Angge Jumba deliberately spread the ghost story to frighten the children so that they would not look for renek at that time. Instead, Angge Jumba and his wife would collect renek at that time and go home before daylight. The story was also made up for the children's safety as well, since it was not a suitable time for them to collect renek.

Other than the folk wisdom concerning the collecting of renek, Arena Wati, in Memoir Arena Wati: Enda Gulingku, also records how the coastal community used to cure shortsightedness. Arena Wati became shortsighted because he spent a lot of time reading. With the help of his friend, Jalle, he was cured. Jalle dripped a mixture of three substances into Arena Wati's eyes. The drops were made from a type of creeping grass, the young leaves of tembatu and a single bulb of shallott. The tembatu leaves were obtained from the tembatu plant also known as jelawai bukit or Neoscortechinia Kingii (prpm.dbp.gov.my). This folk remedy is described by Arena Wati in the following passage:

... saya masih ingat, ubatnya cuma tiga jenis sahaja iaitu sejenis rumput menjalar, berdaun bulat kecil-kecil seperti sisik ikan, bertepi merah dan batangnya menjalar juga berwarna merah, banyak terdapat di tepi lapangan terbang Kallang, jenis rumput ini menjalar di bawah naungan rumput padang yang biasa. Kedua pucuk daun tembatu. Ketiga bawang merah yang ulasnya tunggal sebiji. Bahan inilah yang digiling oleh Jalle, lalu diperah ke mata saya lalu menutup mata saya dengan kapas ...

(... I still remember, the remedy requires only three substances. Firstly, a type of creeping grass with small, rounded, red-rimmed leaves, similar in shape to the scales of a fish and with a creeping stem that is also red in colour; it can be found abundantly near Kallang airport. This type of grass creeps beneath the normal grass. The second ingredient was the young leaves of the tembatu plant. Thirdly, one single shallot. Jalle blended these ingredients, then squeezed the mix into my eyes, after which he covered my eyes with cotton wool ...)

(Arena Wati, 2010:185) 
Arena Wati also includes a tip from the coastal community on how to heal wounds. This folk wisdom is put forth in the novel Pantai Harapan. Apart from reciting chants, the people also used the leaves of "big sage" (Lantana camara) to heal the wound as is shown in this following excerpt:

Lato meneliti luka kaki Lola, lalu dia jampi dan tinggalkan Lola atas balaibalai dan kembali ke pantai membawa sepongkes daun dari rumpun pokok tahi ayam. Lato tumbuk daun itu, baunya pahit-perat dan kembali kepada Lola dan menampalnya ubat itu di kaki Lola lalu membebatnya dengan kain buruk

(Lato examined the wound on Lola's leg, then recited a chant and left Lola on the bench and went back to the shore carrying a basket of leaves from a bush of big sage. Lato pounded the leaves - the smell was pungent - then returned to Lola and placed the poultice on Lola's leg, and wrapped it in a rag.)

(Arena Wati, 1991:11)

This excerpt clearly shows how the leaves of the big sage are used to heal wounds. Medical researchers have discovered that this plant contains an active substance that can heal wounds.

Arena Wati also mentions a folk remedy the coastal community uses to cure diarrhea. This is described in his novel Rindu Aroma Padi Bunting. This remedy is used by Haji Supuk when Raja Nasrun has diarrhea. He gives him a drink of $c i k u$ (sapodilla) fruit boiled together with young leaves from its tree:

“...pagi tadi di Singapura, saya tahu penyakitnya,” kata Haji Supuk, sebelum tiba ke ruang tamu. "Cepat, Engku Raja. Pergi petik buah ciku dan daunnya yang masih muda. Rebus segera air itu beri dia minum."

(“... this morning in Singapore, I know what ailed him" said Haji Supuk, before reaching the sitting room. "Quick, Engku Raja. Go and pick some ciku and some young leaves from its tree. Boil those immediately and give that to him to drink.")

(Arena Wati, 2012: 455)

There is another piece of folk wisdom mentioned by Arena Wati in his novels, on how to drive away sandflies. The sandfly is a small bloodsucking insect like the mosquito and the place where it bites causes pain and itchiness. (Ujud, 2009:32). This insect is often found around beaches, rivers and bushes and can be a threat because it contains a substance that causes the skin to itch. The sandfly usually roams the seaside areas and is 
rather difficult to see and even more difficult to destroy than mosquitoes. The tip is as follows:

Cara yang digunakan untuk menghalau agas ialah dengan memasukkan beberapa jaras sabut kelapa ke dalam api. Asapnya boleh halau agas.

(The way to drive away sandflies is to put several bundles of coconut husks into the fire. The smoke will drive away the sandflies.)

(Arena Wati, 1991:22)

The excerpt above shows that the tip for driving away sandflies is to burn coconut husks.

\section{CONCLUSION}

This essay shows that Arena Wati has recorded many of the tips and remedies that form part of the folk wisdom that communities use to solve various problems, for example, how to ensure a boat sails at its best speed, or how to keep away sandflies, or for curing light ailments such as seasickness and diarrhea. Arena Wati also shows the tips and tricks that coastal communities use to catch catfish, crabs, and renek. Such tips and remedies are also part of the intangible cultural heritage of those communities. This cultural heritage should be preserved because there are tips and tricks that are still suitable for use in modern times. The folk wisdom also shows that the maritime community has a very close relationship with their surroundings, and knows effective ways of using whatever is available in their environment.

\section{REFERENCES}

A. Ghaffar Ahmad, 2010. Pemuliharaan Bangunan Wariasan di Malaysia: Pengalaman dan Cabaran Masa Depan. Syarahan Umum Perlantikan Profesor. Pulau Pinang: Penerbit Universiti Sains Malaysia.

Abu Talib Ahmad (ed.), 2012. Utara Semenanjung Malaysia : Esei-Esei Warisan. Pulau Pinang: Penerbit Universiti Sains Malaysia.

Ahmad Jelani Halimi, 2006. Perdagangan dan Perkapalan Melayu di Selat Melaka: Abad Ke-15 Hingga Ke-18. Kuala Lumpur: Dewan Bahasa dan Pustaka.

Arena Wati, 1990. Pantai harapan. McGraw-Hill/Custom Publishing. Arena Wati, 1991. Citra. Kuala Lumpur: Dewan Bahasa dan Pustaka. Arena Wati, 1994. Sudara. Kuala Lumpur: Dewan Bahasa dan Pustaka dan Kementerian Pendidikan Malaysia. 
Arena Wati, 2000. Sukma Angin. Kuala Lumpur: Dewan Bahasa dan Pustaka.

Arena Wati, 2005. Warna Sukma Usia Muda. Bangi: Penerbit Universiti Kebangsaan Malaysia.

Arena Wati, 2010. Memoir Arena Wati: Enda Gulingku. Bangi: Penerbit Universiti Kebangsaan Malaysia.

Arena Wati, 2012. Rindu Aroma Padi Bunting. Kuala Lumpur: Dewan Bahasa dan Pustaka.

Gamal Komandoko, 2010. Ensiklpoedia Pelajar Umum. Jogyakarta: Penerbit Pustaka Widyatama

Hamidah Abdul Wahab, "Petua dan Pantang Larang Tradisional Dalam Alam Melayu Sarawak" in International Jornal of The Malay World and Civilization (IMAN) 1:1 hlm. 87-97, 2013.

Hersanto Effendy, 1990. Memelihara Maskoki dalam Akuarium. Yogyakarta: Kanisius Kamarudin M. Said, 2012. "Minda Pelaut dan Kenangan Tanah Leluhur dalam Kepengarangan Arena Wati: Tafsiran Fenomenologi" dlm. Rahim Aman (ed.), Minda Pelaut dan Kenangan Tanah Leluhur Kemelayuan Malaysia- Indonesia. Penerbit Universiti Kebangsaan Malaysia.

Dewan Bahasa dan Pustaka, 2007. Kamus Dewan Edisi Keempat. Kuala Lumpur DBP dlm http//:prpm.dbp.gov

Sabda S., 2013. 202 Khasiat Herba. Shah Alam, Selangor: Alaf 21 Group Karang Kraf. Sohaimi Abdul Aziz, 2014. Dahsyatnya Sastera Memerihalkan Kehidupan. Pulau Pinang: Penerbit Universiti Sains Malaysia.

Sohaimi Abdul Aziz, 2015. "Arena Wati dan Makassar: Dari Pelayar dan Pedagang ke Pengarang Cereka Maritim" in Persidangan Kebangsaan Dunia Maritim Nusantara Dalam Pelbagai Perspektif: Sasterawan Negara Arena Wati sebagai Pelayar, Pedagang dan Pengarang, 24 Oktober 2015 di Dewan Kuliah A, USM Sutarmi and Hartin Rozaline, 2006. Taklukan Penyakit dengan VCO. Jakarta: Penebar Swadaya.

Syamsul Hidayat and Rodami M. Napitupulu, 2015. Kitab Tumbuhan Ubat. Jakarta: AgrFlo (Penebar Swadaya Grup).

Ujud Tahajuddin, 2009. Pengembangan Pariwisata Pulau Banyak. Jakarta: Lembaga Ilmu Pengetahuan Indonesia,

Yusmilayati Yunos, "Petua dan Tanda sebagai Alat Komunikasi dalam Budaya Masyarakat Jawa" dalam Fauziah Ahmad (ed). Jurnal Komunikasi: Malaysian Journal of Communication 31:2, 2015.

Received: 2 August 2016

Accepted: 27 September 2016 